Jurnal Manajemen Kesehatan Yayasan RS.Dr.Soetomo Vol.4 No.1 April 2018

Print ISSN 2477-0140 Online ISSN 2581-219X

www.jurnal.stikes-yrsds.ac.id

\title{
Pengetahuan dan Perilaku Merokok Pelajar Sekolah Menengah Pertama
}

\section{Knowledge and Smoking Behavior of Junior High School Student}

\author{
Diah Wijayanti Sutha \\ STIKES Yayasan RS Dr. Soetomo Surabaya \\ Email : diahwsutha@gmail.com
}

\begin{abstract}
ABSTRAK
Remaja merupakan target potensial bagi industri rokok. Hal ini tentu saja sangat mengkhawatirkan dan dibutuhkan edukasi yang intensif kepada para pelajar perokok. Tujuan studi adalah untuk melihat pengetahuan pelajar Sekolah Pertama Negeri (SMPN) terhadap perilaku merokok. Penelitian ini merupakan studi deskriptif dengan pedekatan Cross-sectional. Populasinya adalah semua pelajar di 4 SMPN di Kecamatan Sampang Madura yaitu sebanyak 1.789 pelajar. Teknik pengambilan sampel menggunakan stratified random sampling berdasarkan kelas, diperoleh sampel sebanyak 273 pelajar. Hasilnya, perilaku merokok paling banyak dilakukan pelajar di usia 15 tahun yaitu sebesar 9,1\%. Pelajar dengan rata rata usia 11-16 tahun sudah melakukan aktivitas merokok dimulai pada usia < 10 tahun yaitu sebanyak 48 (48\%) pelajar, dan pelajar yang berusia 15 tahun memiliki angka yang paling banyak memulai usia merokok di usia $<10$ tahun yaitu sebanyak 14 (14,3\%) pelajar. Pelajar yang mempunyai status sebagai perokok semuanya belum pernah mendapatkan penyuluhan tentang bahaya perilaku merokok. Sebanyak 36,3\% pelajar perokok memiliki pengetahuan yang kurang tentang bahaya rokok.
\end{abstract}

\section{Kata Kunci: Perilaku Merokok, Pelajar SMP, Pengetahuan, Remaja}

\section{ABSTRACT}

Adolescents are a potential target for the tobacco industry. This is of course very worrying and requires intensive education to students of smokers. The purpose of the study was to see the knowledge of Junior High School students on smoking behavior. This research is a descriptive study with Cross-sectional approach. The population is all students in 4 Junior High School in Sampang Madura sub-district as much as 1.789 students. The sampling technique using stratified random sampling based on the grade, obtained a sample of 273 students. As a result, Smoking behavior is mostly done by students at the age of 15 years that is equal to 9,1\%. Students with an average age of 1116 years have started smoking activities starting at the age $<10$ years 48 (48\%) of students, and 15-year-old students have the highest number of start smoking at age $<10$ years as many as 14 (14.3\%) of the students. Students who have a status as a smoker have never been educated about the dangers of smoking behavior. As many as $36.3 \%$ of smoker students have less knowledge about the dangers of smoking.

Keywords: Smoking Behavior, Junior High School Students, Knowledge, Adolescents 
Diah Wijayanti Sutha : Pengetahuan dan Perilaku Merokok Pelajar Sekolah...

\section{PENDAHULUAN}

Masalah merokok adalah masalah global yang masih menjadi perhatian hingga saat ini, dan remaja merupakan sasaran utama produk tembakau. Perokok remaja adalah calon pelanggan tetap industri rokok namun menjadi petaka bagi kualitas generasi penerus bangsa, karena jika umur mulai merokok dimulai pada umur 11 tahun atau lebih muda maka akan lebih cenderung menjadi perokok berat dan merokok secara teratur daripada perokok yang mulai merokok pada usia yang lebih tua (Santrock, 2003).

Satu dari dua perokok pada usia muda dan terus merokok seumur hidup hingga akhirnya meninggal karena penyakit yang berhubungan dengan rokok ratarata diderita perokok yang memulai merokok pada usia remaja. Perokok pada usia muda akan meninggal pada usia setangah baya, sebelum 70 tahun, atau kehilangan sekitar 22 tahun harapan hidup normal (WHO, 2013). Remaja sebagai bagian masyarakat yang berada pada umur produktif tersebut menjadi target potensial bagi industri rokok. Pada masa kini kecenderungan mulai merokok pada remaja jauh lebih muda. Di negara berkembang jauh lebih sedikit perempuan yang merokok di tempat umum (2-10\%) dibandingkan di negara industri (20-40\%). Di bandung menunjukkan 16,2\% pelajara merokok sebelum usia 13 tahun, sedangkan proposi pelajar perempuan yang merokok adalah 2,6\%.

Fakta yang dinyatakan oleh Global Youth Tobacco Survey (GYTS) bahwa Indonesia sebagai negara dengan angka perokok remaja tertinggi di dunia. Usia pertama kali mencoba merokok berdasarkan kelompok umur dan jenis kelamin berdasarkan GYTS 2014, dimana sebagian besar laki-laki pertama kali merokok pada umur 12-13 tahun, dan sebagian besar perempuan pertama kali mencoba merokok pada umur $<7$ tahun dan 14-15 tahun. Kecanduan rokok di kalangan remaja merupakan salah satu masalah serius di banyak negara termasuk Indonesia. Berdasarkan data global, lebih dari 17\% remaja berusia 13 sampai 15 tahun mengonsumsi beberapa bentuk tembakau. Dampak negatif rokok bagi remaja memang biasanya terjadi pada beberapa tahun setelah remaja itu mulai merokok aktif, seperti kanker paru-paru. Namun, perlu diketahui bahwa ada beberapa efek jangka pendek yang terjadi cukup cepat. Efek negatif merokok 
yang berlaku pada laki-laki juga berlaku pada perempuan, namun adanya perbedaan struktur tubuh perempuan dengan laki-laki menyebabkan timbulnya efek khusus yang tidak terdapat pada laki-laki.

\section{METODE}

Penelitian ini merupakan studi analitik dengan pedekatan Cross-sectional karena data yang dikumpulkan dalam kurun waktu yang bersamaan dengan teknik survey. Lokasi penelitian ini dilakukan di 4 Sekolah Menengah Pertama Negeri (SMPN) yang berada di Kecamatan Sampang Madura pada bulan 25 April - 7 Juli 2017. Populasi dalam penelitian ini adalah semua pelajar remaja yang berada di Kecamatan Sampang Kabupaten Sampang Madura yaitu sebanyak 1.789 remaja (4 SMP). Pengambilan sampel dilakukan secara acak tanpa memperhatikan strata yang ada. Kriteria inklusi responden pertama, remaja putra atau putri yang berstatus sebagai pelajar Sekolah Menengah Pertama Negeri (SMP N) di Kecamatan Sampang Madura. Kedua, Bersedia menjadi responden.

Teknik pengambilan sampel dilakukan secara acak berstratifikasi (stratified random sampling). Agar perimbangan sampel dari masing-masing strata memadai, maka dalam teknik ini dilakukan perimbangan antara jumlah remaja dari setiap strata. Hal ini disebut proportional stratified random sampling. Asumsi tingkat kelonggaran atau ketidaktelitian sebesar 5\% maka diperoleh sampel penelitian sebesar 273 .

\section{HASIL}

Gambaran usia responden yang merupakan pelajar Sekolah Menengah Pertama Negeri (SMPN) yang ada di Kecamatan Sampang adalah sebagai berikut

Tabel. 1 Distribusi Usia Pelajar Sekolah Menengah Pertama Negeri

\begin{tabular}{lrr}
\hline Usia & Jumlah & $\%$ \\
\hline 11 Tahun & 44 & 16,1 \\
12 Tahun & 52 & 19 \\
13 Tahun & 56 & 20,5 \\
14 Tahun & 57 & 20,9 \\
15 Tahun & 52 & 19 \\
16 Tahun & 12 & 4,4 \\
Total & 273 & 100 \\
\hline
\end{tabular}


Diah Wijayanti Sutha : Pengetahuan dan Perilaku Merokok Pelajar Sekolah...

Berdasarkan tabel 1 dapat disimpulakan bahwa responden yang merupakan pelajar Sekolah Menengah Pertama Negeri (SMPN) mempunyai usia rata-rata pada usia 11 sampai 16 tahun, dimana responden dengan usia 14 tahun mempunyai jumlah yang lebih banyak yaitu sebanyak 57 responden atau sebesar 20,9\%. Sedangkan usia responden yang memiliki jumlah paling sedikit yaitu responden dengan usia 16 tahun sebanyak 12 responden atau sebesar 4,4\%. Sebagian besar responden adalah laki-laki sebanyak 143 responden atau sebesar $52,4 \%$, dan sisanya adalah responden dengan jenis kelamin perempuan sebanyak 130 responden atau sebesar 47,6\%. Distribusi frekuensi perilaku merokok responden dapat dilihat pada tabel 3 berikut :

\section{Tabel 2 Distribusi Perilaku Merokok Pelajar Sekolah Menengah Pertama}

\section{Negeri}

\begin{tabular}{llrr}
\hline No & Perilaku Merokok & Jumlah & $\%$ \\
\hline 1 & Merokok & 98 & 35,9 \\
2 & Tidak Merokok & 175 & 64,1 \\
Jumlah & 273 & 100 \\
\hline
\end{tabular}

Perilaku merokok responden pada pelajar di sekolah menengah pertama negeri di Kecamatan Sampang sebanyak 98 pelajar dari 273 remaja yang ada dengan persentase 35,9\% mempunyai perilaku merokok. Perilaku merokok yang menjadi kriteria dalam penelitian ini adalah responden yang saat ini menjadi perokok atau sebelumnya pernah mencoba merokok. Dari hasil wawancara perilaku merokok tersebut dilakukan oleh responden di rentang usia 10 tahun sampai dengan usia 15 tahun.

Tabel 3 Distribusi Usia Perilaku Merokok Pelajar Sekolah Menengah Pertama Negeri

\begin{tabular}{lrrrrrr}
\hline \multirow{2}{*}{ Usia } & \multicolumn{3}{c}{ Status Merokok } & \multicolumn{2}{c}{ Total } \\
\cline { 2 - 5 } & \multicolumn{2}{c}{ Tidak Merokok } & \multicolumn{2}{c}{ Merokok } & & \\
\cline { 2 - 5 } 11 Tahun & 31 & 11,3 & 13 & 4,8 & 44 & 16,1 \\
12 Tahun & 43 & 15,8 & 9 & 3,3 & 52 & 19,1 \\
13 Tahun & 32 & 11,7 & 24 & 8,8 & 56 & 20,5 \\
14 Tahun & 36 & 13,2 & 21 & 7,7 & 57 & 20,9 \\
15 Tahun & 27 & 9,9 & 25 & 9,1 & 52 & 19 \\
16 Tahun & 6 & 2,2 & 6 & 2,2 & 12 & 4,4 \\
Total & 175 & 64,1 & 98 & 35,9 & 273 & 100 \\
\hline
\end{tabular}


Tabel 3 dapat diambil kesimpulan bahwa saat ini responden yang melakukan perilaku merokok sebesar 98 responden dengan distribusi paling banyak dilakukan responden di usia 15 tahun yaitu sebesar 9,1\%. Data ini merupakan data yang diambil pada responden yang hingga saat ini (saat dilakukannya penelitian) responden tersebut masih melakukan perilaku merokok. Distribusi usia pertama kali memulai aktivitas merokok responden dapat dilihat pada tabel berikut :

\section{Tabel 4 Distribusi Usia Pertama Kali Merokok Pelajar Sekolah Menengah} Pertama

\begin{tabular}{lrr}
\hline Usia Pertama kali merokok & Jumlah & $\%$ \\
\hline$<10$ Tahun & 48 & 49 \\
$10-15$ Tahun & 47 & 48 \\
$\geq 15$ Tahun & 3 & 3 \\
Total & 98 & 100 \\
\hline
\end{tabular}

Tabel 4 menunjukkan bahwa aktivitas merokok pelajar sekolah menengah pertama negeri yang mempunyai perilaku merokok dimulai pada usia $<10$ tahun yaitu sebanyak 48 responden dengan persentase 48\%. Distribusi usia responden saat petama kali memulai aktivitas merokok dengan usia responden pada saat ini perilaku merokok masih dilakukan (saat dilakukannya penelitian) dapat dilihat pada tabel berikut:

Tabel 5 Distribusi Pelajar Sekolah Menengah Pertama Negeri Berdasarkan Usia Pertama Kali Memulai Aktivitas Merokok

\begin{tabular}{|c|c|c|c|c|c|c|c|c|}
\hline \multirow{3}{*}{$\begin{array}{l}\text { Usia Responden } \\
\text { saat ini }\end{array}$} & \multicolumn{6}{|c|}{ Usia Pertama Kali merokok } & \multicolumn{2}{|c|}{ Total } \\
\hline & \multicolumn{2}{|c|}{$<10$ Tahun } & \multicolumn{2}{|c|}{ 10-15 Tahun } & \multicolumn{2}{|c|}{$\geq 15$ Tahun } & & \\
\hline & $\mathrm{n}$ & $\%$ & $\mathrm{n}$ & $\%$ & $\mathrm{n}$ & $\%$ & $\mathrm{n}$ & $\%$ \\
\hline 11 Tahun & 7 & 7,1 & 6 & 6,1 & 0 & 0 & 13 & 13,3 \\
\hline 12 Tahun & 5 & 5,1 & 4 & 4,1 & 0 & 0 & 9 & 9,2 \\
\hline 13 Tahun & 11 & 11,2 & 13 & 13,3 & 0 & 0 & 24 & 24,5 \\
\hline 14 Tahun & 9 & 9,2 & 12 & 12,2 & 0 & 0 & 21 & 21,4 \\
\hline 15 Tahun & 14 & 14,3 & 9 & 9,2 & 2 & 2,0 & 25 & 25,5 \\
\hline 16 Tahun & 2 & 2,0 & 3 & 3,1 & 1 & 1,0 & 6 & 6,1 \\
\hline Total & 48 & 49 & 47 & 47 & 3 & 3 & 98 & 100 \\
\hline
\end{tabular}

Tabel 5 diatas menjelaskan bahwa responden dengan rata rata usia 11-16 tahun sudah melakukan aktivitas merokok dimulai pada usia $<10$ tahun yaitu sebanyak 48 responden dengan persentase 48\%, dan remaja saat ini yang berusia 15 tahun memiliki angka yang paling banyak memulai usia merokok di usia $<10$ tahun yaitu sebanyak 14 orang atau sebesar 14,3\%. Perilaku merokok sebagian 
besar di lakukan oleh pelajar dengan jenis kelamin laki-laki yaitu sebanyak 94 responden atau sebesar 34,4\% dari 143 pelajar laki-laki yang ada. Sedangkan pelajar perempuan yang mempunyai status sebagai perokok hingga saat ini berjumlah 4 orang atau sebanyak 1,5\% dari 130 pelajar perempuan sekolah menengah pertama negeri yang ada di Kecamatan Sampang. Tingkat pengetahuan responden tentang bahaya rokok dan kandungannya dapat dilihat pada tabel berikut:

Tabel 6 Tingkat Pengetahuan Pelajar Sekolah Menengah Pertama Negeri

\begin{tabular}{clrr}
\hline No & Tingkat Pengetahuan Tentang Bahaya & Jumlah & $\%$ \\
& Merokok & 30 & 11 \\
\hline 1 & Baik & 50 & 18,3 \\
2 & Cukup Baik & 193 & 70,7 \\
3 & Rendah & 273 & 100 \\
& Jumlah & & \\
\hline
\end{tabular}

Pengetahuan yang menjadi penilaian disini adalah merupakan kemampuan responden mengetahui serta memahami bahaya rokok, kandungan rokok, dan efek rokok bagi orang lain disekitar perokok. Pengetahuan responden tentang bahaya merokok sebagian besar pada kategori rendah yaitu sebesar 70,7\% dan sebesar 18,3\% yang berpengetahuan cukup dan sebanyak 11\% berpengetahuan baik. Hasil analisis terhadap jawaban responden pada pernyataan/ pertanyaan mengenai pengetahuan tentang bahaya merokok dapat dilihat pada paparan hasil adalah sebagai berikut :

\section{Tabel 7 Jawaban Tingkat Pengetahuan Tentang Bahaya Merokok pada} Pelajar Sekolah Mengah Pertama

\begin{tabular}{|c|c|c|c|}
\hline No & Pernyataan & Benar & Salah \\
\hline 1 & Merokok dapat menyebabkan gangguan kesehatan & 193 & 80 \\
\hline 2 & Sebuah rokok mengandung lebih dari 4000 jenis bahan kimia & 82 & 191 \\
\hline 3 & $\begin{array}{l}\text { Sebuah rokok mengandung } 40 \text { bahan yang dapat menyebabkan } \\
\text { kanker }\end{array}$ & 72 & 201 \\
\hline 4 & $\begin{array}{l}\text { Rokok tidak dapat menimbulkan dampak pada tubuh dalam } \\
\text { beberapa menit }\end{array}$ & 201 & 72 \\
\hline 5 & $\begin{array}{l}\text { Nikotin yang terkandung dalam rokok dapat menyebabkan } \\
\text { kecanduan }\end{array}$ & 56 & 217 \\
\hline 6 & $\begin{array}{l}\text { Tingkat Tar dalam rokok merupakan faktor yang } \\
\text { mempengaruhi timbulnya kanker paru-paru }\end{array}$ & 61 & 212 \\
\hline 7 & $\begin{array}{l}\text { Jumlah rokok terhirup dalam satu hari adalah faktor yang } \\
\text { mempengaruhi timbulnya kanker paru-paru }\end{array}$ & 74 & 199 \\
\hline 8 & $\begin{array}{l}\text { Seorang wanita hamil yang merokok menimbulkan gangguan } \\
\text { untuk kehamilannya }\end{array}$ & 197 & 76 \\
\hline
\end{tabular}




\begin{tabular}{clcc}
\hline No & \multicolumn{1}{c}{ Pernyataan } & Benar & Salah \\
\hline 9 & $\begin{array}{l}\text { Jika saya merokok tanpa menghirup, tidak akan menimbulkan } \\
\text { efek pada tubuh saya }\end{array}$ & 237 & 36 \\
10 & $\begin{array}{l}\text { Saya seorang perokok pasif jika ada seorang yang merokok di } \\
\text { sekeliling saya }\end{array}$ & 112 & 161 \\
11 & $\begin{array}{l}\text { Menghisap rokok dari orang lain tidak memiliki efek buruk } \\
\text { bagi tubuh saya }\end{array}$ & 189 & 84 \\
12 & $\begin{array}{l}\text { Perokok pasif tidak memiliki kemungkinan terkena kanker } \\
\text { paru-paru }\end{array}$ & 213 & 60 \\
13 & $\begin{array}{l}\text { Anak- anak yang dikelilingi oleh orang yang merokok tidak } \\
\text { mengalami gangguan pada kesehatannya }\end{array}$ & 221 & 52 \\
14 & $\begin{array}{l}\text { Merokok beberapa batang rokok tidak akan merusak kesehatan } \\
\text { Perokok bisa berhenti merokok dengan mudah kapan saja }\end{array}$ & 177 & 96 \\
\hline & & 174 & 99 \\
\hline
\end{tabular}

Tabel 7 memperlihatkan bahwa sebagian besar responden mengetahui bahwa perilaku merokok dapat menyebabkan gangguan kesehatan. Namun dalam hal bahan-bahan bahaya yang terkandung dalam rokok yang masih kurang dipahami oleh responden. Hal ini dapat dilihat dari hampir separuh menjawab salah karena tidak bisa menyebutkan bahan berbahaya yang dapat mengganggu kesehatan yang terkandung dalam rokok, masih ada 237 responden atau 86,8\% responden menganggap bahwa asap saja yang berbahaya bagi kesehatan bukan bahan yang terkandung dalam rokok yang lainnya. Hasil analisis antara tingkat pengetahuan dengan perilaku merokok diperoleh nilai $P=0,000<\alpha=0,05$. Dapat disimpulkan bahwa ada hubungan antara tingkat pengetahuan dengan perilaku merokok. Tingkat pengetahuan yang baik dan cukup seharusnya mendukung individu untuk berperilaku sehat, dalam hal ini tidak merokok.

\section{PEMBAHASAN}

Karakteristik subjek penelitian ini adalah dilihat dari usia, sebagian besar responden berusia 14 tahun yaitu sebesar 20,9\% dan berjenis kelamin laki-laki yaitu sebesar 52,4\%, semua responden berstatus sebagai pelajar sekolah menengah pertama negeri yang berada di Kecamatan Sampang. Dalam penelitian ini menggambarkan bahwa perilaku merokok, baik yang saat ini masih merokok maupun pernah mencoba merokok, semua dilakukan oleh remaja laki-laki, hal ini juga sependapat dengan penelitian Martini, 2015 yang menyatakan bahwa jenis kelamin mempengaruhi perilaku merokok seseorang, hasil penelitian tersebut juga menyatakan bahwa perilaku merokok remaja cenderung lebih besar dilakukan 
oleh laki-laki, banyak hal yang mendorong perilaku tersebut terjadi, diantaranya adalah komunitas tempat remaja tersebut bermain. Hal yang memprihatinkan adalah usia mulai merokok yang setiap tahun semakin muda. Bila dulu orang mulai berani merokok biasanya mulai SMA maka sekarang dapat dijumpai anakanak SD kelas 5 sudah mulai banyak yang merokok secara diam-diam. Prevalensi perokok di Indonesia kian hari semakin meningkat dan memprihatinkan. Fakta yang dikeluarkan oleh Riseksas 2013 peningkatan tertinggi perokok di Indonesia terjadi pada kelompok remaja umur 15-19 tahun, yaitu dari 7,1 persen pada tahun 1995 menjadi 17,3 persen pada tahun 2004, atau naik 144 persen selama 9 tahun.

Patut diperhatikan bahwa belakangan ini kejadian perilaku meningkat pada remaja perempuan. Pada hasil penelitian ini juga didapat bahwa dari total 130 pelajar Sekolah Pertama Negeri yang ada di Kecamatan Sampang, ada 4 orang perempuan yang mempunyai perilaku merokok. Perempuan perokok dilaporkan menjadi percaya diri, suka menentang, dan secara sosial cakap, keadaan ini berbeda dengan perokok laki-laki yang secara sosial tidak aman. Pada saat ini, peningkatan kejadian merokok tidak hanya terjadi pada remaja laki-laki. Begitupun dengan perempuan, perempuan yang merokok dilaporkan menjadi percaya diri, suka menentang dan mandiri. Namun pada kasus ini karena pengaruh adanya budaya yang menganggap bahwa merokok merupakan hal yang sangat tercela untuk perempuan, hal ini menekan tumbuhnya perokok perempuan yang ada di daerah peneliti.

Siswa Sekolah Menengah Pertama atau MTS pada umumnya adalah siswa usia remaja. Remaja sebagai periode tertentu dari kehidupan manusia merupakan suatu konsep yang relatif baru dalam kajian psikologi. Menurut Mu’tadin, Zaenum., (2002), perilaku dan pribadi siswa MTS/ SMP sudah memasuki masa remaja. Hal ini dijelaskan lebih lanjut bahwa rentangan masa remaja itu berlangsung dari sekitar 11-13 tahun sampai 18-20 tahun menurut umur kalender kelahiran seseorang. Masa remaja terbagi menjadi dua, yaitu masa remaja awal (usia 11-13 tahun sampai 14-15 tahun) dan masa remaja akhir (usia 14-16 tahun sampai 18-20 tahun). Dengan demikian siswa MTS/ SMP yang dijadikan subyek penelitian penulis termasuk dalam golongan masa remaja awal. 
Masa remaja merupakan sebuah periode dalam kehidupan manusia yang batasan usia maupun peranannya seringkali tidak terlalu jelas. Masa remaja ini sering dianggap sebagai masa peralihan, dimana saat-saat ketika anak tidak mau lagi diperlakukan sebagai anak-anak, tetapi dilihat dari pertumbuhan fisiknya ia belum dapat dikatakan orang dewasa. Menurut Ng, N., Nichter (2010) masa remaja juga dikenal dengan masa strom and stress dimana terjadi pergolakan emosi yang diiringi pertumbuhan fisik yang pesat dan pertumbuhan psikis yang bervariasi. Pada masa ini remaja mudah terpengaruh oleh lingkungan dan sebagai akibatnya akan muncul kekecewaan dan penderitaan, meningkatnya konflik dan pertentangan, impian dan khayalan, pacaran dan percintaan, keterasinagan dari kehidupan dewasa dan norma kebudayaan (Gunarsa, 1989).

Beberapa penelitian di Indonesia menunjukkan bahwa kebanyakan orang mulai merokok ketika duduk di bangku Sekolah Menengah Pertama atau kurang lebih pada usia 12 tahun (Aditama, 1998). Pada penelitian ini, sebanyak 49\% responden menyetakan bahwa mereka memulai aktivitas merokoknya pada umur $\leq 10$ tahun. Dapat disimpulkan bahwa usia perokok remaja semakin dini dilakukan saat ini, karena menurut Riskesdas (2010), usia merokok remaja dimulai pada umur 10 tahun. Remaja memiliki potensi yang lebih besar untuk menjadi adiksi terhadap rokok. Umumnya remaja memiliki persepsi bahwa mereka dapat berhenti merokok, tidak akan kecanduan, atau akan terhindar dari efek buruk dari merokok. Pada sebuah studi berkelanjutan menunjukan bahwa perokok ringan usia remaja akan cenderung mengalami transisi menjadi perokok berat pada dua tahun setelah lulus dari sekolah.

Hasil penelitian ini menyebutkan bahwa usia perokok remaja pada pelajar SMPN di Kecamatan Sampang paling banyak dilakukan oleh remaja berusia 14 tahun, hasil ini didukung oleh Infodatin (Pusat Data dan Informasi Kementerian Kesehatan RI, 2016) yang menyatakan bahwa trend usia perokok di Indonesia diketahui meningkat pada remaja dan terjadi pada perokok berumur 15-19 tahun, dan perokok 10-14 tahun diprediksi akan semakin meningkat. Hasil Riskesdas pada tahun 2007, 2010 dan 2013 menunjukkan bahwa usia mulai merokok pertama kali paling tinggi adalah pada kelompok umur 15-19 tahun. 
Diah Wijayanti Sutha : Pengetahuan dan Perilaku Merokok Pelajar Sekolah...

Penelitian ini menyebutkan bahwa perilaku merokok didominasi oleh pelajar dengan jenis kelamin laki-laki yaitu sebanyak 94 orang atau 34,4\% pada usia 14 tahun. Penelitian ini didukung oleh data dari Infodatin (Pusat Data dan Informasi Kementerian Kesehatan RI, 2016) yang menyatakan bahwa perilaku merokok remaja umumnya dilakukan oleh remaja laki-laki pada rentang umur antara $>14$ tahun.

Global Youth Tobacco Survey (GYTS) menyatakan Indoensia sebagai negara dengan angka perokok remaja tertinggi di dunia. Selain itu, gambar di atas menggambarkan usia pertama kali mencoba merokok berdasarkan kelompok umur dan jenis kelamin berdasarkan GYTS 2016, dimana sebagian besar laki-laki pertama kali merokok pada umur 12-13 tahun, dan sebagian besar perempuan pertama kali mencoba merokok pada umur $\leq 7$ tahun dan 14-15 tahun.

Hasil penelitian ini memang menyebutkan bahwa perilaku merokok sebagian besar memang dilakukan oleh pelajar laki-laki, dari 98 perokok pelajar yang ada 94 orang dilakukan oleh pelajar laki-laki, namun pelajar perempuan yang memiliki aktivitas merokok yang dimulai di rentang umur 10-15 tahun didapat 4 orang responden, dan tentunya hal ini sangat memperihatinkan. Hasil ini dikuatkan oleh pernyataan dari WHO. Data WHO tahun 2014 menyebutkan statistik perokok dari kalangan remaja Indonesia yaitu 24,1\% remaja laki-laki adalah perokok dan 4,0\% remaja perempuan adalah perokok.

Jumlah remaja perempuan perokok di Indonesia memang tidak sebanyak jumlah remaja laki-laki perokok. Namun, dari data-data yang ada menyebutkan bahwa jumlah perokok perempuan terus meningkat. Tidak hanya itu, prevalensi merokok pada remaja perempuan lebih tinggi dibandingkan prevalensi pada perempuan dewasa. Pada tahun 2008, berdasarkan hasil riset yang dilakukan oleh Koalisis untuk Indonesia Sehat (KuIS) tercatat bahwa 43,33\% dari perempuan muda Indonesia sudah atau pernah merokok. Ini menujukkan bahwa banyak remaja perempuan yang tertarik menjadi perokok.

Kenaikan jumlah perempuan perokok di Indonesia tidak sebanyak pada lakilaki. Jumlah perokok laki-laki juga lebih banyak dibandingkan jumlah perempuan perokok. Perilaku merokok pada laki-laki adalah perilaku yang dianggap normal 
oleh masyarakat Indonesia. Bahkan perilaku merokok pada laki-laki di Indonesia dianggap sebagai simbol kejantanan. Selain itu pendapat bahwa merokok dapat meningkatkan kejantanan laki-laki juga banyak dipromosikan lewat iklan-iklan rokok (Ng, N., Nicher, 2010). Sementara laki-laki merokok dapat diterima oleh masyarakat Indonesia, dari sisi budaya perempuan dianggap menyimpang. Secara tradisional, perempuan di Indoensia tidak pantas merokok, namun data menunjukkan bahwa ada peningkatan jumlah perokok perempuan.

Kesetaraan gender dari sudut pandang substansi maupun persepsi, digunakan oleh industri tembakau dalam mengiklankan produknya melalui citra emansipasi, keanggunan, kemandria, dan kebebasan menentuka pilihan, dalam menargetkan pasar perempuan (17,18\%). Hal ini terbukti dengan peningkatan perokok wanita di Indonesia setiap tahunnya yang semula hanya 1,7\% pada tahun 1995 menjadi 6,7\% pada tahun 2013 (Riskesdas, 2013). Belum lagi beban keluarga perokok dan pemerintah untuk menanggung biaya sakit akibat penyakit yang berhubungan dengan tembakau dan hilangnya produktifitas dan sumber nafkah keluarga karena kematian dini. Kosen (2004) dalam studinya tentang beban ekonomi akibat konsumsi tembakau di Indonesia memperkirakan pada tahun 2001 terdapat sekitar 5.160.075 penderita yang berhubungan dengan konsumsi tembakau.

Pada penelitian telah dibuktikan bahwa risiko kanker paru 7,8 kali lebih besar pada perokok dibandngkan dengan bukan perokok. Di samping itu, angka fertilitas dan impotensi dapat terjadi pada wanita perokok aktif dan pasif, keduanya mempunyai peningkatan risiko tertundanya kemampuan menjadi hamil. Untuk laki-laki, merokok juga meningkatkan risiko impotensi sampai dengan 50\%. Data-data ini membuktikan bahwa akibat penggunaan rokok akan mempengaruhi derajat kesehatan reproduksi sehingga akan mempengaruhi kualitas generasi yang akan datang.

Pengetahuan responden tentang bahaya merokok sebagian besar pada kategori rendah yaitu sebanyak 193 responden atau sebesar 70,7\%. Hasil penelitian menyebutkan bahwa sebagian besar responden telah mengetahui bahaya dari perilaku merokok. Namun dalam hal bahan-bahan bahaya yang 
Diah Wijayanti Sutha : Pengetahuan dan Perilaku Merokok Pelajar Sekolah...

terkandung dalam rokok yang masih kurang dipahami oleh responden. Hal ini dapat dilihat dari hampir separuh berpengetahuan salah karena tidak bisa menyebutkan bahan berbahaya yang dapat mengganggu kesehatan yang terkandung dalam rokok, masih ada responden menganggap bahwa asap saja yang berbahaya bagi kesehatan bukan bahan yang terkandung dalam rokok yang lainnya. Hasil penelitian menyatakan bahwa ada hubungan antara pengetahuan dengan perilaku merokok, dan remaja yang mempunyai perilaku merokok dari hasil penelitian ini disebutkan juga mempunyai pengetahuan yang rendah terhadap bahaya perilaku merokok.

Pada penelitian ini juga didapat hasil bahwa reponsen yang mempunyai pengetahuan cukup baik juga mempunyai perilaku merokok terdapat 4 responden atau sebesar 1,5\%. Tingkat pengetahuan yang baik dan cukup seharusnya mendukung individu untuk berperilaku sehat, dalam hal ini tidak merokok. Hal ini tidak terjadi pada responden yang merokok. Responden tetap merokok walaupun memiliki tingkat pengetahuan yang sedang akan bahaya rokok. Green, Kaar, dan WHO telah mengidentifikasi faktor-faktor yang mempengaruhi individu untuk berperilaku tertentu. Banyak faktor, selain pengetahuan, yang mempengaruhi individu untuk berperilaku merokok, antara lain adanya pengaruh kelompok sebaya, adanya contoh dari orang dewasa, dan kemudahan dalam mendapatkan rokok dan sebagainya.

Menurut Widati (2012), bahwa remaja merokok karena melihat iklan di media massa dan elektronik yang menampilkan gambaran bahwa perokok adalah lambang kejantanan atau glamour, membuat remaja seringkali terpicu untuk mengikuti perilaku seperti yang ada dalam iklan tersebut. Meski semua orang tahu akan bahaya yang ditimbulkan akibat merokok, perilaku merokok tidak pernah surut dan tampaknya merupakan perilaku yang masih dapat ditolerir oleh masyarakat. Hal ini dapat dirasakan dalam kehidupan sehari-hari di lingkungan rumah, kantor, angkutan umum maupun jalan-jalan. Hampir setiap saat dapat disaksikan dan dijumpai orang yang sedang merokok. Bahkan bila orang merokok di sebelah ibu yang sedang menggendong bayi sekalipun orang tersebut tetap tenang menghembuskan asap rokok dan biasanya orang-orang di sekelilingnya 
tidak peduli.

Bahaya merokok bagi remaja diantaranya dapat meningkatkan risiko kanker paru-paru dan penyakit jantung diusia yang masih muda. Selain itu kesehatan kulit tiga kali lipat lebih berisiko terdapat disekitar mata dan mulut. Kulit akan menua sebelum waktunya atau biasa disebut penuaan dini. Merokok diusia dini menyebabkan impotensi dan mengurangi jumlah sperma pada pria dan mengurangi tingkat kesuburan pada wanita. Remaja mulai merokok karena berbagai alasan, seperti: meniru kebiasaan orang dewasa, tekanan dari teman sebaya, faktor kepribadian karena alasan ingin tahu, pengaruh iklan, dan meniru sifat orang yang terkenal yang biasanya merokok. Namun sangat disayangkan karena tidak hanya kebiasaan yang baik saja yang ditiru, melainkan juga kebiasaan buruk termasuk kebiasaan merokok.

Adanya pengetahuan tentang bahaya merokok, maka anak akan terhindar kebiasaan merokok ataupun menghindari asap rokok dari orang-orang sekitarnya. Oleh karena itu, diperlukan kepedulian dari kalangan akademisi untuk ikut serta turut berbagi ilmu pengetahuan tentang bahaya rokok bagi kesehatan. Perilaku merokok yang dimulai sejak remaja menjadi sebuah ancaman bagi kesehatan. Hal ini dihubungkan dengan besarnya kemungkinan remaja mengalami adiksi pada sisa hidupnya. Remaja yang mengalami adiksi akan terpapar asap rokok lebih lama dan meningkatkan risiko terjadinya penyakit yang ditimbulkan oleh asap rokok seperti kanker paru-paru, empisema, kanker tenggorokan, stroke, penyakit jantung iskemik, dan kanker mulut.

\section{UCAPAN TERIMA KASIH}

Ucapan terima kasih dapat diberikan terima kasih yang sebesar-besarnya kepada STIKES Yayasan Rumah Sakit dr. Soetomo selaku institusi asal peneliti, Keluarga besar dan seluruh staff SMP N 1 Sampang, SMP N 2 Sampang, SMP N 3 Sampang, dan SMP N 4 Sampang yang telah memberikan ijin kepada peneliti untuk melakukan peneliti di lingkungan sekolah tersebut. Semua Siswa SMP N 1 Sampang, SMP N 2 Sampang, SMP N 3 Sampang, dan SMP N 4. Semua teman di Mstar (Komunitas Masyarakat Asap Rokok). 
Diah Wijayanti Sutha : Pengetahuan dan Perilaku Merokok Pelajar Sekolah...

\section{DAFTAR PUSTAKA}

Aditama, TY.,(2006) Rokok dan Kesehatan. Jakarta: Universitas Indonesia, hal.42-51

Erikson, E.H., (1963). Childhood and Society. New York: Norton \& Company

Global Youth Tobacco survey. Tobacco Atlas. 2014. http://www.cdc.gov/tobacco/global/gtss/tobacco_atlas/pdfs/part3.pdf (Sitasi 11 November 2016)

Gunarsa, Singgih, D., (1988) Psikologi Remaja. Jakarta: Gunung Mulia

Martini, Santi dan Sulistyowati, Muji., (2005) 'The Determinants Of Smoking Behavior Among Teenagers In East Java Province, Indonesia’. Economics Of Tobacco Control Paper No. 32.http://www wds.worldbank.org/external/default/WDSCotentServer/WDSP/IB/2005/12 /27/000090341_20051227134151/Rendered/PDF/347660IN0YouthSmoki ng0HNP0Tobacco032.pdf (Sitasi 12 Desember 2016)

Mu'tadin, Zaenum., (2002) Kemandirian Sebagai Kebutuhan Psikologi Pada Remaja. from http://www.damandiri.or.Id/detail.php?id=340.html.diunduh tanggal 25 januari 2016.

Ng, N., Nichter, M., Prabandari, Y. S., Muramoto, M., (2010) Bringing Smoking Cessation to Diabetes Clinics in Indonesia. Chronic Illness, 6(2), 125-135.

RISKEDAS,(2010) http://www.litbang.depkes.go.id/sites/download/buku_laporan lapnas_riskesdas2010/Laporan_riskesdas_2010.pdf (sitasi 18 Desember 2016)

RISKESDAS. (2013) https://www.k4health.org/sites/default /files/laporan Nasional\%20Riskesdas\%202013.pdf (Sitasi 18 Desember 2016)

Santrock, J.W., (2003) Adolescence: Perkembangan Remaja. Jakarta: Penerbit Erlangga.

WHO, (2007) The Scientific Basis of Tobacco Product Regulation. Switzerland: WHO Press (Sitasi 24 November 2014).

WHO, (2013) World Health Statistics report. http://www.who.int /gho/publications/world_health_statistics/EN_WHS2013_Full.pdf (Sitasi 24 November 2016).

Widati, S., (2012) Integrated Marketing Communications (IMC) Berperilaku Sehat Tanpa Rokok Pada Remaja Masyarakat Miskin di Kota Surabaya, Disertasi. Program Pascasarjana Universitas Airlangga Surabaya. Program Studi Kesehatan Masyarakat. 